\title{
Micromorphological and Chemical Features of Soils as Evidence of Bronze Age Ancient Anthropogenic Impact (Late Bronze Age Muradymovo Settlement, Ural Region, Russia)
}

\author{
Alexandra Golyeva ${ }^{1, *(D)}$, Olga Khokhlova ${ }^{2}$, Marina Lebedeva ${ }^{3}$ (D), Nickolay Shcherbakov 4 (iD) \\ and Iia Shuteleva 4 \\ 1 Institute of Geography, Russian Academy of Sciences, 119017 Moscow, Russia \\ 2 Institute of Physical, Chemical and Biological Problems in Soil Science, Russian Academy of Sciences, \\ Ulitsa Institutskaya, 2, Pushchino, 142290 Moscow, Russia; olga_004@rambler.ru \\ 3 V.V. Dokuchaev Soil Science Institute, 119017 Moscow, Russia; m_verba@mail.ru \\ 4 Archaeological Laboratory of Bashkir State Pedagogical University, 450076 Ufa, Russia; \\ sherbakov@rambler.ru (N.S.); shutelevai@gmail.com (I.S.) \\ * Correspondence: golyevaaa@yandex.ru; Tel.: +07-916-3294335
}

Received: 24 July 2018; Accepted: 16 August 2018; Published: 22 August 2018

\begin{abstract}
In some cases, the human impact on ancient landscapes has been so profound that local soils still remain significantly affected even after hundreds and thousands of years after ending impact. We studied the Late Bronze Age Muradymovo settlement located in the Urals, Russia, aiming to estimate the consequences of the ancient people's activity on the environment. Despite the present humid climate, the modern soils inside the cultural layer of the study site contain more than $27 \%$ of gypsum at a depth of just $10 \mathrm{~cm}$ from the surface, and a microrelief of the study site is typical of a gypsum desert. The nearby background Chernozems are gypsum-free to a depth of $2 \mathrm{~m}$. According to the archaeological data, the ancient people belonged to the 'Srubno-Alakul' archaeological culture (1750-1350 years B.C. cal (calibrated years before Christ)) and had a tradition of building their houses from gypsum rocks. At the present time, this area is still unsuitable for human settlement. The properties of modern soils inside the cultural layer of the study site are directly affected by the Late Bronze Age human activities. It has been identified on soil morphology, micromorphology, and chemical properties of soils developed inside the cultural layer of the settlement.
\end{abstract}

Keywords: Bronze Age settlement; modern soil; micromorphology; chemical properties; gypsum; anthropogenic impact

\section{Introduction}

In some cases, the human impact on ancient landscapes has been so profound that local soils still remain significantly affected even after hundreds and thousands of years after ending impact [1-9]. There are no natural soils left within such sites, being replaced by completely different anthropogenic soils with specific properties [10-17].

Studying the causes and implications of such negative influences of past human activities on soils and environment is necessary to prevent similar accidents in the future. The present article describes a case study of the extremely severe and long-lasting impact of ancient people on soils and environment. The study site is the Late Bronze Age settlement of Muradymovo, located in Bashkortostan Republic (Urals region, Russia). The site and its area have a peculiar hillocky microrelief that doesn't occur anywhere else in Bashkortostan Republic. According to the archaeological 
data $[18,19]$, the Muradymovo people belonged to the 'Srubno-Alakul' culture of the Late Bronze Age and came here from an especially arid semidesert region of southern Kazakhstan, where they used to build their houses of gypsum rocks. There is a deposit of gypsum rocks just $5 \mathrm{~km}$ away from the Muradymovo settlement site [20].

In our previous paper, we gave the general description of this settlement [21], whereas the aim of the current work was to investigate the micromorphological and chemical properties of the modern soils and the cultural layer at the Bronze Age settlement Muradymovo to estimate the consequences of the ancient people's activity on the environment.

\section{Materials and Methods}

The study site ( $\left.53^{\circ} 58^{\prime} 44.8^{\prime \prime} \mathrm{N}, 55^{\circ} 30^{\prime} 58.8^{\prime \prime} \mathrm{E}\right)$ is located $2.5 \mathrm{~km}$ north of the village of Muradymovo, in the Aurgazinskiy District of the Bashkortostan Republic of Russia (Figure 1). The site of the Muradymovo ancient settlement, having a total area of $6 \mathrm{ha}$, is found on the first terrace at the right bank of the Urshak River, $0.2 \mathrm{~km}$ east of the main stream, on a hill about $1.5-2 \mathrm{~m}$ high. The bedrock is composed of gypsum, anhydrite, dolomite, and sandstone of the Kungur stage of the Permian Period. The bedrock is overlain by loess-like silty sediments (approximately 8-10 $\mathrm{m}$ thick) of the Quaternary Period that serve as parent rocks for soils.

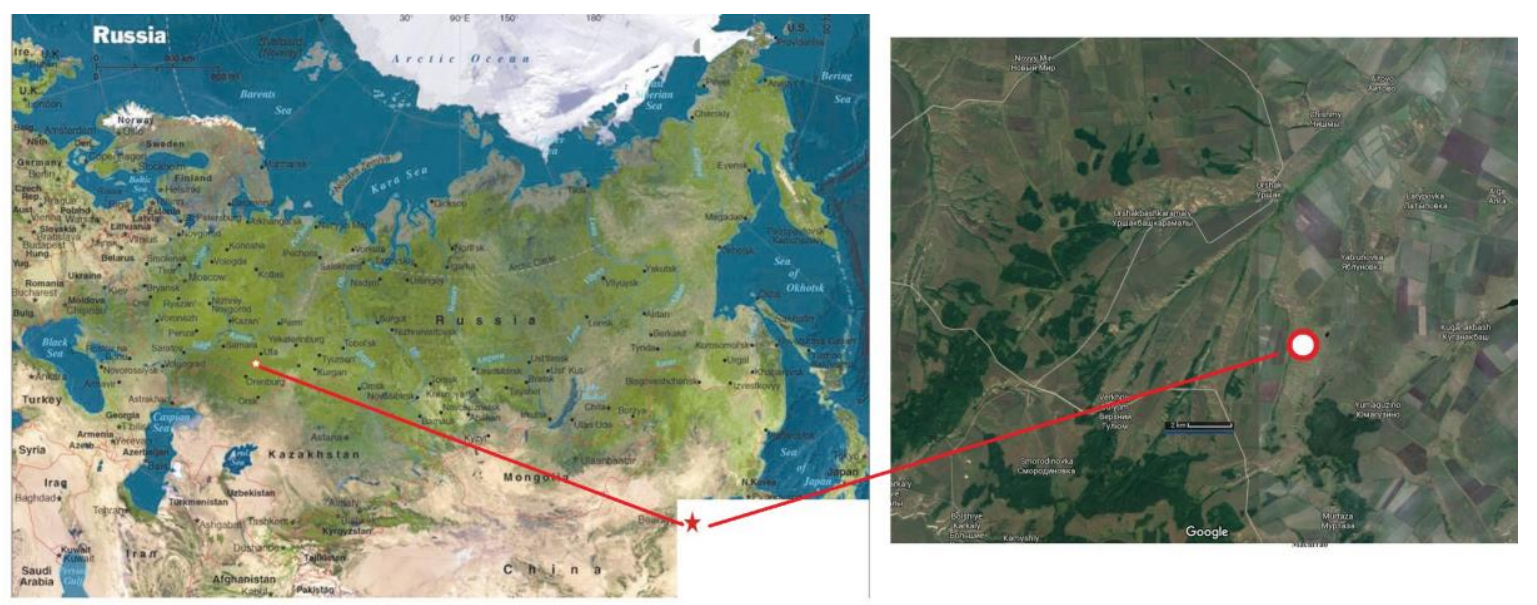

Figure 1. Study site location.

Climate is continental, moderately cold. The mean annual air temperature is $+2.5{ }^{\circ} \mathrm{C}$, with the mean temperatures of January and July being $-15{ }^{\circ} \mathrm{C}$ and $+19.5^{\circ} \mathrm{C}$, respectively. The mean annual precipitation is about $500 \mathrm{~mm}$, with more than $300 \mathrm{~mm}$ falling during the growing season. The hygrothermal coefficient is about 1 [22].

The typical modern vegetation is represented by steppe communities.

The typical soils are Calcic Chernozems (Loamic) [23] that are naturally gypsum-free to a depth of more than $3 \mathrm{~m}[24,25]$.

According to the archaeological data [26,27], the settlement was built by ancient people of the 'Srubno-Alakul' archaeological culture of the Late Bronze Age (1750-1350 years B.C. cal), who lived here for no longer than 200-300 years. Later, the settlement remained abandoned. At present, the site is covered with sparse steppe vegetation, partially used as a pasture and bordered by a gully from the west and north. No archaeological artefacts of other cultures were found on this site. There are no signs of plowing. We concluded that after the abandonment in the Bronze Age time, this area was only used as a pasture from time to time.

We studied the archaeological excavation pit (no IV) having the most representative morphology of cultural layers (Figure 2a). The pit included several layers of house remains (no less than 5) and a hearth (i.e., this residential house was rebuilt several times). 
The background soil outcropping from the bank of a small river at a short distance from the archeological excavation site was also studied. This soil was least affected by the ancient settlement construction; it was located on the opposite bank and had no traces of ancient human impact (Figure 2b).

The modern microrelief consists of small hillocks separated by deep frost cracks, which cover the whole area of the study site and beyond, up to the banks of the river and gully. Frost cracks result from recent influence of continental climate. The hillocks are about $50 \mathrm{~cm}$ high and $1.5-2.2 \mathrm{~m}$ long. Such peculiar microrelief is absent at the other side of the gully.

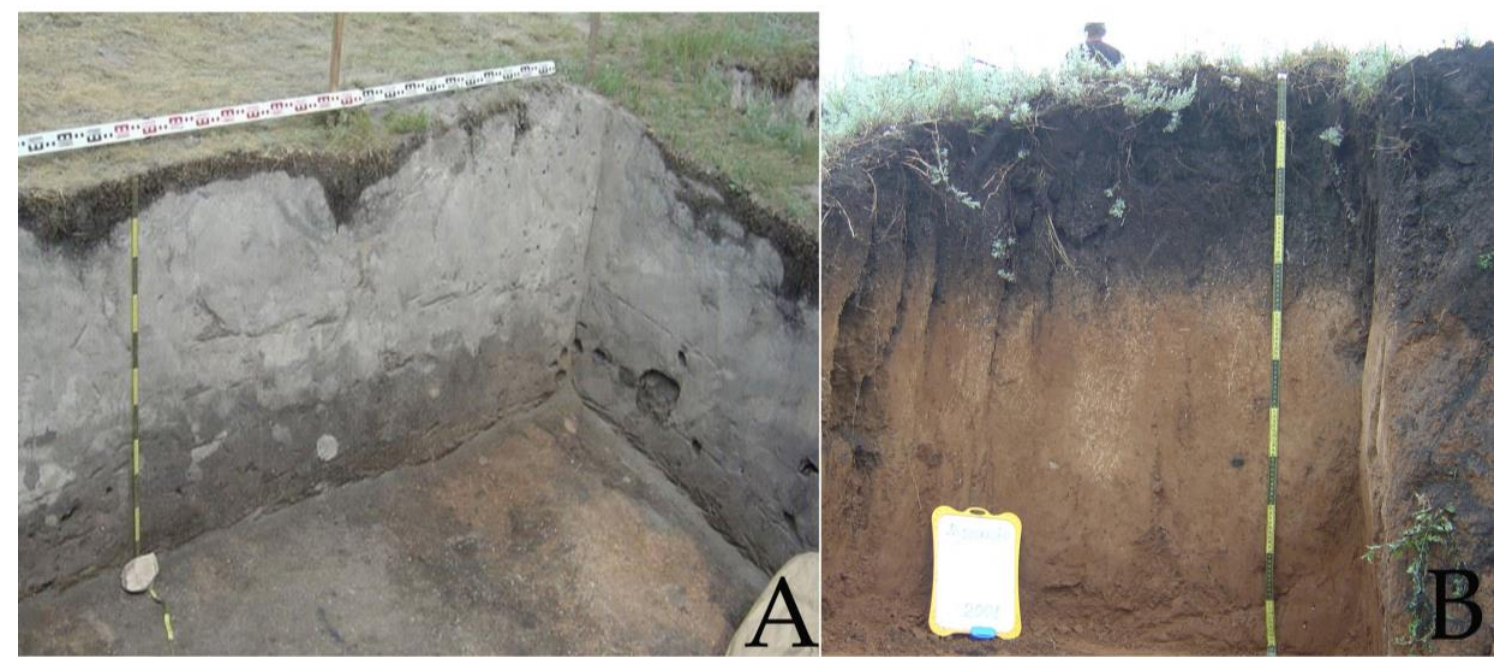

Figure 2. Soil profiles: A—archaeological pit; B—background soil.

We described morphological characteristics of the pit within the settlement and the profile of background soil, collected samples in vertical columns in the field, and conducted micromorphological and chemical analyses of the samples in the laboratory using conventional techniques [28-30]. The samples were prepared according to the requirements for each specific analysis.

Micromorphological observations were carried out on thin sections $(3 \mathrm{~cm} \times 4 \mathrm{~cm}$ and $30 \mu \mathrm{m}$ thick) which were prepared from undisturbed soil samples from the upper part $(10-20 \mathrm{~cm})$, from the lower part (60-70 cm from the surface) of the cultural layer, and from the humus horizon $(10-20 \mathrm{~cm})$ of the background soil. They were studied using an Olympus BX51 TL RL Pol microscope (Olympus, Tokyo, Japan) and an Olympus DP 25 digital camera (Olympus, Tokyo, Japan) at the V.V. Dokuchaev Soil Science Institute, Moscow, and using a polarizing microscope Carl Zeiss HBO 50 (Carl Zeiss AG, Oberkochen, Germany) in the Chemical-Analytical Complex of the Institute of Physical, Chemical and Biological Problems in Soil Science, Russian Academy of Sciences, Pushchino.

The mineralogical composition of the dry residue of the water extract from the cultural layer samples taken at the depths of 10-20 and 60-70 cm was determined by X-ray diffraction in the Laboratory of Soil Mineralogy and Micromorphology of the V.V. Dokuchaev Soil Science Institute by Dr. E. Varlamov. The analysis was conducted using an HZG-4A universal X-ray diffractometer (Carl-Zeiss, Jena, Germany) with the following settings: $\mathrm{Cu}$ radiation, $30 \mathrm{kV}$ tube voltages, $20 \mathrm{~mA}$ current, and a scan speed of $2^{\circ}-2 \Theta$ per minute. Calculations were performed using 'Difraktometr-Avto 2014' software produced by the LLC Iris.

The procedure to determine the total phosphorus included the sample combustion with concentrated sulfuric acid. Phosphate in the extract was determined calorimetrically using a SPECOL 211 spectrophotometer (Analytik Jena AG, Germany) and a blue ammonium molybdate method with ascorbic acid as a reducing agent [30].

Gypsum was determined using $10 \% \mathrm{BaCl}_{2}$ solution [28]. Each sample was boiled for 3 minutes in $0.2 \mathrm{~N} \mathrm{HCl}$, cooled for $30 \mathrm{~min}$, and passed through a filter. The filtrate was diluted with distilled water 
and passed through $\mathrm{H}$-cationite. The resulting solution was titrated with $\mathrm{BaCl}_{2}$ solution. The obtained values of $\mathrm{SO}_{4}$ concentrations were recalculated for gypsum $\left(\mathrm{CaSO}_{4} \times 2 \mathrm{H}_{2} \mathrm{O}\right)$.

The amount of $\mathrm{pH}_{\mathrm{H} 2 \mathrm{O}}$ was determined using a potentiometer, in suspension with soil to water ratio of 1:2.5, after a single shaking followed by settling for $30 \mathrm{~min}$ [28].

The organic carbon was determined by the Tyurin method, which included the wet combustion of organic substance in a mixture of $0.4 \mathrm{~N} \mathrm{~K}_{2} \mathrm{Cr}_{2} \mathrm{O}_{7}$ and concentrated $\mathrm{H}_{2} \mathrm{SO}_{4}(1: 1)$ at $150{ }^{\circ} \mathrm{C}$ for $20 \mathrm{~min}$. The measurements were performed by photometry on a SPECOL 211 spectrometer at $590 \mathrm{~nm}$ [28].

Calcium carbonate concentrations in the samples were determined by alkalimetry using the Kozlovskii procedure. A soil sample was treated with $2 \mathrm{M} \mathrm{HCl}$; the released $\mathrm{CO}_{2}$ was absorbed by a $0.4 \mathrm{M} \mathrm{NaOH}$ solution. Then, a saturated $\mathrm{BaCl}_{2}$ solution was added to the tube with $\mathrm{NaOH}$, and the excess of alkali was titrated with $0.2 \mathrm{M} \mathrm{HCl}$ [30]. The obtained values of the carbonate ion concentrations were recalculated for calcium carbonates.

\section{Results}

\subsection{Morphological Description}

The soils studied were considerably different from each other (Figure 2).

\subsubsection{Modern Soil (Background or Reference Soil)}

Undisturbed background soils of the site were attributed to Calcic Chernozems (Loamic) and were characterized by the following features: a humus profile with the $\mathrm{Ah}+\mathrm{AhB}$ horizons $50-70 \mathrm{~cm}$ thick, followed by a carbonate-accumulative horizon $\mathrm{Bk}$ to a depth of $110 \mathrm{~cm}$ with the maximum occurrence of carbonate pedofeatures in the form of vertical chains of white soft spots (or soft carbonate nodules) at a depth of 90-110 cm, which, in turn, was followed by the soil-forming rock. The signs of burrowing animals' activity in the profiles were apparent: in the upper horizons, the structure was coprogenic and the AhB horizons contained dark gray and pale yellow animal holes; in the Bk horizon, a number of thin, long passages filled with humus material were found; there were no fresh holes with a clear contour, but only indistinct, diffused ones.

The background (reference) soil had features typical for Chernozems of the studied region, with the organomineral horizon thicker than $50 \mathrm{~cm}$, underlain by the calcic horizon.

\subsubsection{The Soil inside the Cultural Layer}

The section was studied under forb-grassy vegetation. Soil of the excavation pit IV had a light-colored surface layer containing diffuse secondary calcium sulfate and abundant pottery artefacts, bones, and charcoal. According to archaeological data [26], it was the layer of habitation deposits. Under the habitation deposits, a well-preserved and morphologically distinct buried soil was found. We added the index "cul" to two surface horizons of the studied soil, meaning that those horizons are developed inside the cultural layer.

Asod cul, 0-3 cm. Sod horizon.

A1 cul, 3-7 (20) cm. Black, slightly dry, light loamy, with fine crumb structure; slightly compacted; siliceous powdering on ped faces; densely penetrated by roots; clear, smooth, tongue-like boundary.

Cultural Layer, 7 (20)-80 (86) cm. Light grayish pale, slightly dry, light loamy, structureless; powdery (ashlike); soft nodules and filaments of calcareous pseudomycelium with a characteristic size of $0.3-0.6 \mathrm{~cm}$; roots; animal bones of $2-3$ to $10-15 \mathrm{~cm}$ in size; fragments of broken pottery, clear boundary.

[A], 80 (86)-106 cm. Black, slightly dry, heavy loam with coarse columnar-prismatic structure, calcareous powdering on ped faces; diffuse boundary.

[AB], 106-116 cm. Dark ocherous brown, with humus streaks, slightly wet heavy loam, fine columnar-prismatic structure; with ocherous-colored mottles. 


\subsection{Micromorphological Description}

The humus horizon of modern background soil had weakly separated granular microstructure, complex packing voids, small granules with great content of organic fine material, plant tissue residues, and signs of mezofauna activity in voids (Figure 3a,b); the plant tissue residues had visible cell structure surrounded by brown and black small granules, signs of mite activity, speckled b-fabric (Figure 3c,d), and no gypsum.

In the soil inside the cultural layer, two samples, at 10-20 and 60-70 cm depths, were compared. They had similarities and differences in their microfabric. The similarities included the absolute predominance of gypsum grains of various sizes and habits in the soil skeleton composition and the presence of granular peds consisting of isotropic amorphous organic fine material (Figure 4a-h) [31].

The differences between the compared samples are expressed by quantitative rather than by the qualitative distinctions between prevailing forms of gypsum crystals and sizes of organic granular peds, as described below.

Dominant features in the layer at the 10-20 cm depth were as follows: (1) gypsum crystals of two types: a) aggregates of corroded thin prismatic crystals (on average, about $30 \mu \mathrm{m}$ long) between humus granular peds, many of which were covered with humus coatings, and b) thick infillings of very dense and small (about $0.05 \mu \mathrm{m}$ ) tabular gypsum crystals in channel pores containing fine residues of plant tissues (Figure 4a-d); (2) relatively large crumb peds $(100-140 \mu \mathrm{m})$ that consisted of agglomerated small granular peds (with an average size of about 40-50 $\mu \mathrm{m}$ ); (3) bone fragments that were very small and rare; (4) rare micrite crystals [31].
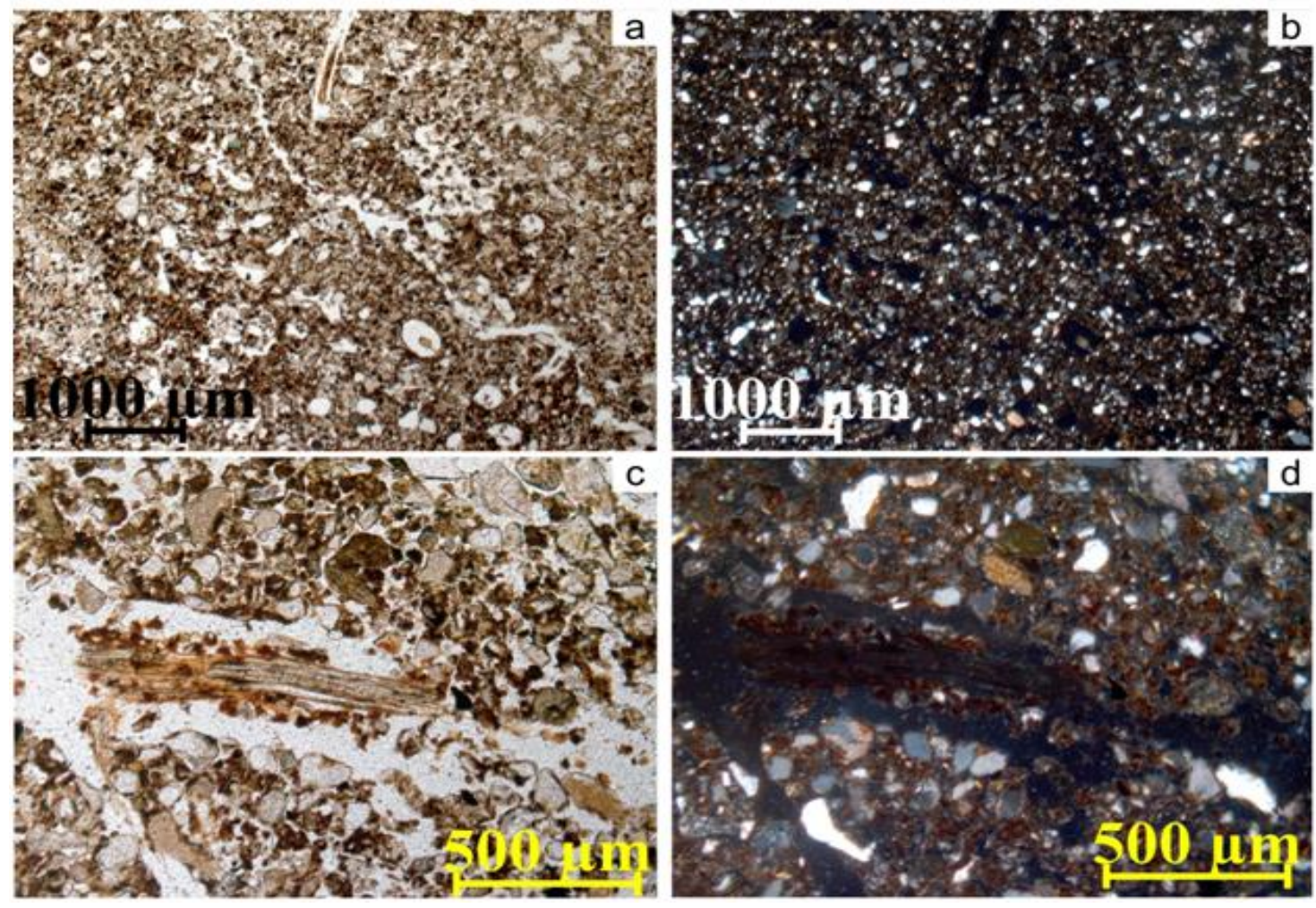

Figure 3. Micromorphological features of the humus horizon of modern reference soil at the depth 10-20 cm: a,b-weakly separated granular microstructure, complex packing voids, small granules with great content of organic fine material, tissue residues, and signs of mezofauna activity in voids (a-PPL; $\mathbf{b}-\mathrm{XPL}$ ); $\mathbf{c}, \mathbf{d}-$ tissue residue with visible cell structure surrounded by brown and black small granules, signs of mite activity, speckled $b$-fabric, complex packing voids (c-PPL; $\mathbf{d}-\mathrm{XPL}$ ). 

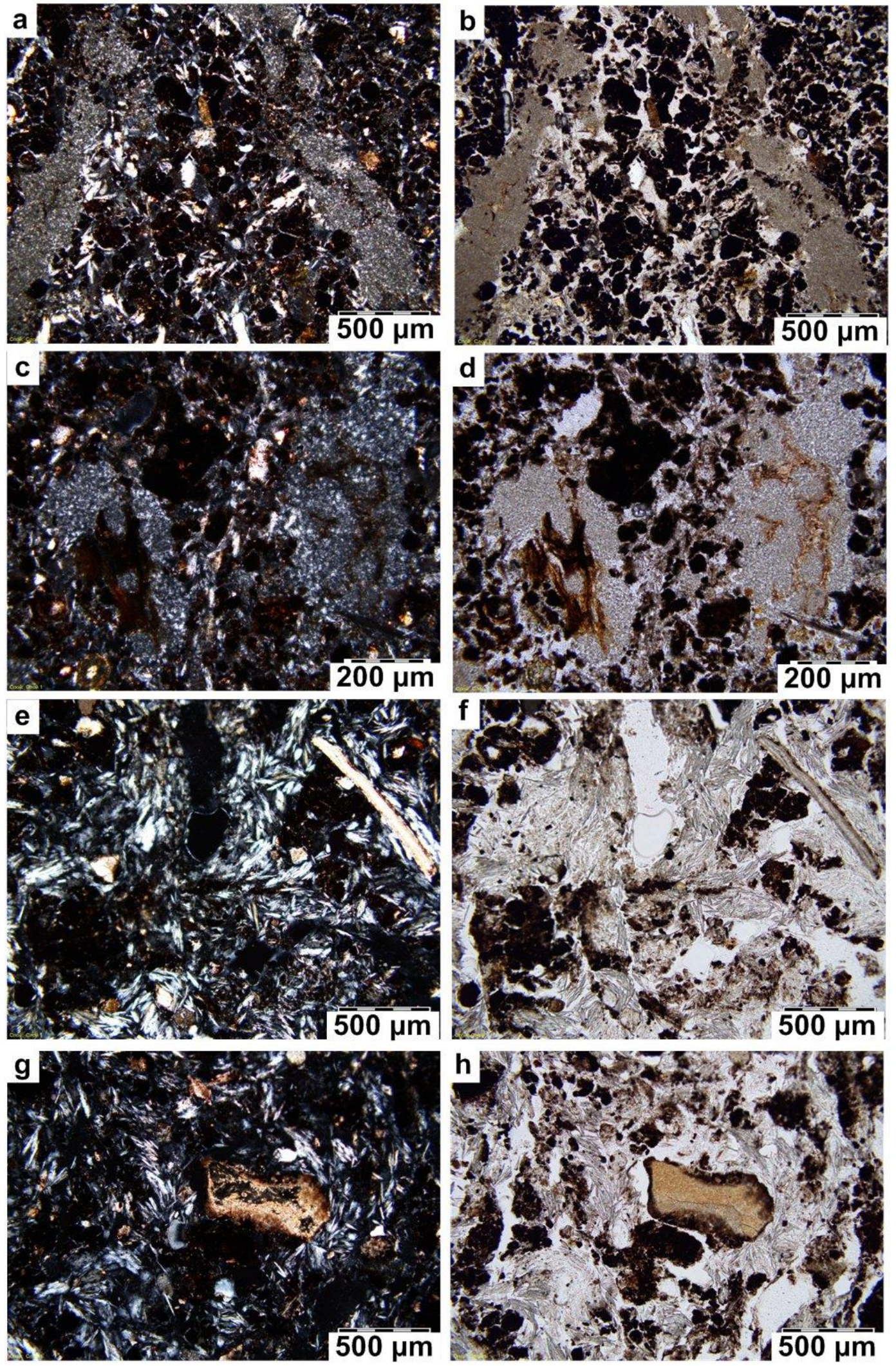

Figure 4. Micromorphological features of soil within the cultural at different depths: $10-20 \mathrm{~cm}(\mathbf{a}-\mathbf{d})$; 60-70 $\mathrm{cm}(\mathbf{e}-\mathbf{h})$. a-d-thick infillings of very dense and small (about $0.05 \mu \mathrm{m}$ ) tabular gypsum crystals in channel pores containing fine residues of plant tissues $(\mathbf{a}, \mathbf{c}-\mathrm{XPL} ; \mathbf{b}, \mathbf{d}-\mathrm{PPL}) ; \mathbf{e}, \mathbf{f}-$ loose continuous infillings composed of lenticular and acicular gypsum crystals; $g, h$-particles of bones with the carbonates (e,g-XPL; $\mathbf{f}, \mathbf{h}-\mathrm{PPL})$. 
At the depth of $60-70 \mathrm{~cm}$, compared to the above sample, the number of humus aggregates was significantly lower and gypsum was a main soil-forming mineral. Among gypsum crystals, aggregates (clusters) of regularly shaped acicular gypsum crystals predominated. They formed loose continuous infillings formed of lenticular and acicular gypsum crystals in pores between soil peds (Figure 4e,f). These infillings had only a few microzones with microfeatures of recrystallization resulting in formation of very small tabular gypsum crystals, similar to those prevailing within dense pore infillings containing plant tissues at the $10-20 \mathrm{~cm}$ depth. Humus microaggregates occurring in rarer groups had features of fragmentation due to the growth of acicular gypsum crystals within certain microzones and also contained long fragments of aragonite. Compared to the above sample, this layer had an increased number of large fragments of bones with microfeatures of their carbonatization and/or small micrite concentrations over small fragments of bones. Large fragments of bones had humus coatings on their surface (Figure $4 \mathrm{~g}, \mathrm{~h}$ ).

\subsection{The Mineralogical Investigation of Dry Residue of Water Extract}

The analysis of X-ray diffraction patterns of powder samples from the compared samples in the soil within the cultural layer (10-20 and $60-70 \mathrm{~cm}$ depths) has revealed that their mineralogical composition is similar: only gypsum minerals with characteristic diffraction peaks are present in the dry residue of water extract (Figure 5). No other mineral salts have been identified.

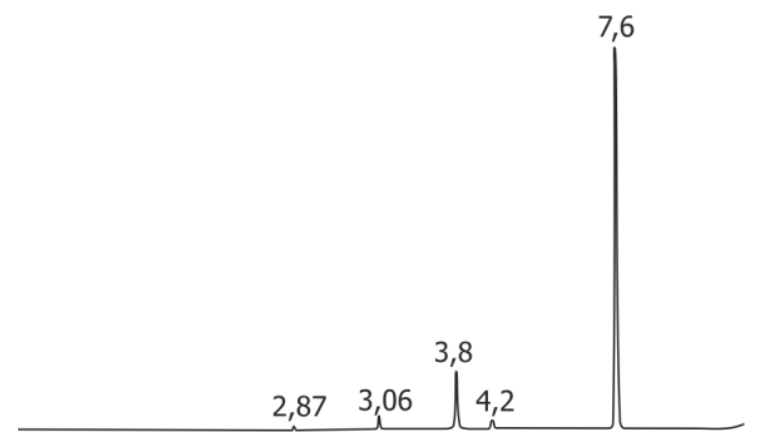

Figure 5. Results of X-ray diffractions.

\subsection{Chemical Analyses}

The results of chemical analyses are presented in Table 1.

The background reference soil had a neutral reaction within its upper part and alkaline within its lower part. A similar $\mathrm{pH}$ distribution pattern is typical for native soils of the study region.

The organic carbon content and distribution were typical for the Chernozems [22], with the maximal organic carbon content within the upper $50 \mathrm{~cm}$, followed by a sharp decrease in deeper layers.

The content of $\mathrm{P}_{\text {tot }}$ in soil was low in comparison with the anthropogenic soils of the excavation pit. The highest values $(0.21 \%)$ occurred within the litter horizon, while the mineral horizons had a uniform small concentration of phosphorus, which is typical for native soils.

Calcium carbonate content was low within the upper 40-cm-thick layer and significantly increased in deeper layers, which is also usual for the native soils.

The gypsum content was almost zero until the $70 \mathrm{~cm}$ depth. At the very bottom of the profile, there was a very small peak of gypsum and calcium carbonate concentration.

Regarding the excavation pit IV (residential house), the soil inside the cultural layer had a neutral reaction within its upper part and alkaline within its lower part. A similar $\mathrm{pH}$ distribution pattern is typical for native soils of the study region and reflects the general trend of downward migration of calcareous soil solutions. The organic matter content was high throughout the soil profile. The maximum amount of organic matter was concentrated within the upper 10-cm-thick layer, which is generally typical for Chernozems. 
Table 1. Chemical properties of soils and cultural layers.

\begin{tabular}{|c|c|c|c|c|c|}
\hline $\begin{array}{c}\text { Depth, cm } \\
\text { Horizon }\end{array}$ & $\mathrm{pH}_{\mathrm{H} 2 \mathrm{O}}$ & Corg, \% & $P_{\text {tot }} \%$ & $\mathrm{CaCO}_{3}, \%$ & $\mathrm{CaSO}_{4}, \%$ (Gypsum) \\
\hline \multicolumn{6}{|c|}{ Pit IV, Inhabited House } \\
\hline 0-5 Asod cul & 7.9 & 8.4 & 0.48 & 3.4 & 0.7 \\
\hline 5-10 Ah cul & 8.3 & 6.6 & 0.64 & 15.3 & 1.9 \\
\hline 10-20 Ah + Cultural layer & 8.3 & 2.2 & 0.26 & 9.5 & 49.8 \\
\hline 20-30 Cultural layer & 8.2 & 1.6 & 0.29 & 13.6 & 49.9 \\
\hline 30-40 Cultural layer & 8.2 & 1.7 & 0.42 & 15.3 & 39.2 \\
\hline 40-50 Cultural layer & 8.2 & 1.3 & 0.50 & 14.4 & 38.2 \\
\hline 50-60 Cultural layer & 8.0 & 1.6 & 0.48 & 19.4 & 8.0 \\
\hline 60-70 Cultural layer & 7.9 & 1.3 & 0.48 & 15.9 & 31.4 \\
\hline 70-80 Cultural layer & 7.9 & 0.9 & 0.45 & 18.4 & 25.6 \\
\hline 80-86 [Ah] & 8.0 & 1.2 & 0.38 & 24.6 & 3.9 \\
\hline 86-96 [Ah] & 8.4 & 1.4 & 0.21 & 33.1 & 1.3 \\
\hline $96-106[\mathrm{Ah}]$ & 8.6 & 1.0 & 0.19 & 38.3 & 2.7 \\
\hline 106-116 [AhB] & 9.1 & 1.0 & 0.19 & 42.2 & 2.3 \\
\hline \multicolumn{6}{|c|}{ Background Reference Soil } \\
\hline 0-10 Ah & 7.4 & 4.5 & 0.21 & 3.4 & 0 \\
\hline $10-20 \mathrm{Ah}$ & 8.0 & 3.1 & 0.17 & 1.7 & 0 \\
\hline 20-30 Ah & 8.2 & 2.7 & 0.15 & 0 & 0 \\
\hline 30-40 Ah & 8.2 & 1.8 & 0.10 & 0 & 0 \\
\hline $40-50 \mathrm{Ah}$ & 8.3 & 1.3 & 0.08 & 1.8 & 0 \\
\hline 50-60 Ah & 8.3 & 1.5 & 0.08 & 4.5 & 0 \\
\hline 60-70 AhB & 8.3 & 0.7 & 0.07 & 9.3 & 0 \\
\hline 70-80 Bk & 8.2 & 0.5 & 0.07 & 15.7 & 0 \\
\hline $80-90 \mathrm{Bk}$ & 8.2 & 0.3 & 0.07 & 18.6 & 0.2 \\
\hline 90-100 Bk & 8.2 & 0.7 & 0.08 & 23.2 & 0.2 \\
\hline $100-110 \mathrm{Bk}$ & 8.3 & - & 0.08 & 23.3 & 0.03 \\
\hline
\end{tabular}

The $P_{\text {tot }}$ distribution was irregular. The cultural layers occurring at $0-86 \mathrm{~cm}$ depth were characterized by a high content of total phosphorus (0.26-0.64\%). The buried Chernozem $(86-96 \mathrm{~cm}$ depth) had a lower $P_{\text {tot }}$ content, virtually equal to that in the uppermost layer of the modern background soil.

The $\mathrm{CaCO}_{3}$ content was high throughout the profile, being slightly higher in its lower part.

The gypsum content and distribution were very unusual. In the field, at a macromorphological scale, the cultural layer of the excavation pit appeared to be composed of whitish-gray, ash-like material, relatively homogeneous, compacted, with inclusions of various artefacts. The laboratory analyses have revealed that the cultural layer was composed of a mixture of gypsum and organic matter, with a small amount of calcium carbonate. The data obtained (Table 1) show that a high content of gypsum (more than $49 \%$ ) is registered within the cultural layer at the depths from 10 to $86 \mathrm{~cm}$, with a gradual downward decrease. The surface layer $(0-10 \mathrm{~cm})$ was relatively impoverished in gypsum $(1.3 \%)$ as a result of leaching.

\section{Discussion}

The upper horizons of the pit IV is the ancient cultural layer, according to their morphological characteristics and the archaeological data [26]. The modern background soil bears no traces of former human impact.

Regarding the background soil, by the content and distribution of $\mathrm{P}_{\text {tot }}$, the modern soil adequately reflects its natural background level, which can be used as a reference for separating the natural and anthropogenic layers: the former are poor in phosphorus, while the latter are characterized by the $\mathrm{P}_{\text {tot }}$ content above $0.22 \%$. 
A small amount of calcium carbonate within the uppermost horizon has a biogenic origin, resulting from the calcium carbonate uptake by plant roots and its return to soil upon the death and decay of those roots [32-34]. This is a general natural phenomenon for soils of the steppe regions of Russia.

The very limited amount of gypsum in the background soil is natural for soils developed in modern climatic conditions of the study region.

With regards to the excavation pit IV, there is an overall decrease of the organic matter content with depth, with occasional humus-rich lenses. These lenses in the upper layers apparently result from man-made depositions of the organic matter during the period of settlement building and exploitation and indicate the cultural layer. Similar lenses in the lower layers, deeper than $86 \mathrm{~cm}$, are a part of the organic matter of the buried paleosol.

The "saw-tooth" pattern of the $P_{\text {tot }}$ distribution within the total depth of the cultural layers reflects the stages of increase and decrease of anthropogenic pressure during the settlement functioning [12,35-37]. There is no phosphorus depletion within the upper $10 \mathrm{~cm}$, which is surprising after such a long period (more than 3000 years) following the abandonment of this site. Perhaps, presence of phosphorus within the surface layer could be its uptake by plants with subsequent decomposition of plant material. In addition, the high amount of gypsum in the cultural layer may serve as a "fixing factor" for phosphorus.

In this excavation pit, the content of calcium carbonate is significantly higher than that in background soil. The latter is calcareous only at depths of more than $50 \mathrm{~cm}$, while the excavation pit profile is calcareous from a $5 \mathrm{~cm}$ depth. Such large concentrations at a shallow depth are typical for the sites of ancient settlements [37]. They are residues of limestone that was used as a house-building material. Calcium carbonate forms almost insoluble complexes with phosphates and organic matter [35]. That is why even under a percolative water regime, the cultural layers of settlements are calcareous.

Comparing the content of gypsum and calcium carbonates revealed a change in the use of bonding agents in the mud bricks for house building [26]. The bonding agents were $\mathrm{CaCO}_{3}$-based at the beginning of the site occupation and later changed to gypsum. At the final stages of settlement existence, gypsum was used with insignificant or no calcium carbonate content.

Infillings of gypsum are clearly pedogenic since they are accumulations in pores. Commonly, the presence of gypsum-saturated groundwater, under a nonpercolating soil water regime, creates the conditions for precipitation of gypsum in macropores and the formation of these pedofeatures $[29,38]$. The study of thin sections has revealed that dense gypsum infillings formed of tabular microcrystals (at the depth of 10-20 cm) and loose continuous infillings composed of lenticular and acicular gypsum crystals (at the depth of $60-70 \mathrm{~cm}$ ) are modern gypsum pedofeatures. They can be formed by two different processes: first, crystallization from solutions saturated with $\mathrm{Ca}^{2+}$ and $\mathrm{SO}_{4}{ }^{2-}$ that are drawn upwards by plant roots; second, presumably, recrystallization of more ancient narrow prismatic crystals of gypsum (corroded forms of which are found within the upper part of the cultural layer) to form acicular crystals. Large fragments of bones have microfeatures of both their carbonatization and the development of collomorphic organic coatings on their surfaces. The collomorphic micromorphotype of humus having a well-developed crumb or granular structure is formed under strongly hydromorphic conditions.

The analyses have shown that there is a high concentration of sulphates in the water extract of soil solution, which favors the migration and recrystallization of gypsum throughout the ancient cultural layer.

Gypsum crystals are present even at the surface of the studied soil inside the cultural layer, which is dramatically different from the background soil, which contains no gypsum in the whole profile.

The present-day gradual dissolution of these salts results in the wider distribution of saline solutions beyond the settlement area. The high rainfall of the region causes calcium sulfate swelling, which leads to significant increases in the volume of the gypsum horizon and the further development 
of the characteristic hummocky microrelief. Such microrelief is often for gypsum deserts $[39,40]$ and absent in this part of Bashkortostan, which is within the natural steppe zone. The understanding of the reasons for the development of such unusual microrelief and gypsum-enriched soils is important for further study and interpretation of any similar archaeological sites in the region.

\section{Conclusions}

On the basis of the data obtained, it can be confidently concluded that the gypsum-bearing strata in the upper part of the excavation pit have an anthropogenic origin. In other words, people built their houses of mud bricks made of a mixture of gypsum and organic matter (manure, for example), occasionally with the addition of small amounts of calcareous rocks.

There is almost pure gypsum within the cultural layer, representing a consecutive series of houses built one after another at the same place. Accumulation of large amounts of gypsum rocks within the ancient settlement site resulted in contamination of the environment with gypsum.

During the period of abandonment of this site, the pedogenic processes homogenized the cultural layer of construction pits. The leaching of salts during the wet seasons was accompanied by the process of upward migration and precipitation of salts during occasional summer droughts as well as severe frosts. Still, the residual amount of gypsum is large after more than 3000 years after contamination. Therefore, it can be assumed that the initial man-made soil contamination by gypsum was extremely strong. The properties of the modern soil inside the cultural layer were directly affected by the Late Bronze Age human activities, with 3-3.5 thousand years being an insufficient timescale to restore the natural gypsum-free soils.

Author Contributions: A.G. and O.K. performed the expedition with fieldwork and soil sampling, conceived and designed the experiments, and wrote the paper; N.S. and I.S. organized and conducted the archaeological excavation, provided all the archaeological information; M.L. performed micromorphological analysis and determination of mineralogical composition of the water extract. All together we discussed the obtained data and corrected the text.

Funding: This research received no external funding.

Acknowledgments: The archaeological excavation was supported by the Russian Foundation for Basic Research (project No. 16-11-02003). The field work and laboratory analyses of soils were supported by the Russian Science Foundation (project No. 16-17-10280) and by the State program of FANO RAS No. 0148-2016-0003. We also thank Inga Spiridonova and Michael Hayes for correcting the English language.

Conflicts of Interest: The authors declare no conflict of interest. The funding sponsors did not take part in the design of the study; in the collection, analyses, or interpretation of data; in the writing of the manuscript; or in the decision to publish the results.

\section{References}

1. Bettis, E.A. Pedogensis in late prehistoric Indian mounds, upper Mississippi valley. Phys. Geogr. 1988, 9, 263-279.

2. Weiss, T.J.; Courty, M.-A.; Wetterstrom, W.; Guichard, F.; Senior, L.; Meadow, R.; Curnow, A. The genesis and collapse of third millennium north Mesopotamia civilization. Science 1993, 261, 995-1004. [CrossRef] [PubMed]

3. Lima, H.N.; Schaefer, C.E.R.; Mello, J.W.V.; Gilkes, R.J.; Ker, J.C. Pedogenesis and pre-Colombian land use of "Terra Preta Anthrosols" ("Indian black earth") of Western Amazonia. Geoderma 2002, 110, 1-17. [CrossRef]

4. Trofimov, S.Y.; Yakimenko, O.S.; Sedov, S.N.; Dorofeeva, E.I.; Gorshkova, E.I.; Zazovskaya, E.P.; Oleinik, S.A.; Demin, V.V. Composition and properties of organic matter in the soils of ancient Slavic settlements in the forest zone. Eurasian Soil Sci. 2004, 37, 927-936.

5. Plekhanova, L.N.; Demkin, V.A. Ancient soil disturbances in river valleys within the steppe zone of the southeastern Urals. Eurasian Soil Sci. 2005, 38, 973-982.

6. Aleksandrovskii, A.L. Pyrogenic origin of carbonates: Evidence from pedoarchaeological investigations. Eurasian Soil Sci. 2007, 40, 471-477. [CrossRef] 
7. Khokhlova, O.S.; Khokhlov, A.A.; Kuznetsova, A.M.; Morgunova, N.L.; Chichagova, O.A. Paleosols buried under kurgans of the Pit-grave culture in the steppe zone of the Cis-Ural region. Eurasian Soil Sci. 2008, 41, 481-490. [CrossRef]

8. Markiewicz, M.; Bednarek, R.; Jankowski, M.; Świtoniak, M. 'Paleotechnosols' of ancient settlements in Grodno and Kałdus. In Technogenic Soils of Poland; Charzyński, P., Hulisz, P., Bednarek, R., Eds.; Polish Society of Soil Science: Torun, Poland, 2013; pp. 111-121.

9. Sànchez-Pèrez, S.; Solleiro-Rebolledo, E.; Sedov, S.; McClung de Tapia, E.; Golyeva, A.; Prado, B.; Ibarra-Morales, E. The black San Pablo paleosol of the Teotihuacan Valley, Mexico: Pedogenesis, fertility, and use in ancient agricultural and urban systems. Geoarchaeology 2013, 28, 249-267. [CrossRef]

10. Woods, W.I.; McCann, J.M. The anthropogenic origin and persistence of Amazonian dark earths. In Yearbook (Conference of Latin Americanist Geographers); University of Texas Press: Austin, TX, USA, 1999; Volume 25, pp. 7-14.

11. Nicosia, C.; Balista, C.; Cupitò, M.; Ertani, A.; Leonardi, G.; Nardi, S.; Vidale, M. Anthropogenic deposits from the Bronze Age site of Fondo Paviani (Verona, Italy): Pedochemical and micropedological characteristics. Quat. Int. 2011, 243, 280-292. [CrossRef]

12. Engovatova, A.; Golyeva, A. Anthropogenic soils in Yaroslavl (Central Russia): History, development, and landscape reconstruction. Quat. Int. 2012, 265, 54-62. [CrossRef]

13. Jankowski, M.; Kittel, P. Evidences of soil-forming processes in red colored Ochre soils (Rubic Arenosols) at the Szynkielew archaeological site, Central Poland. In Proceedings of the 14th International Working Meeting on Soil Micromorphology, Lleida, Spain, 8-14 July 2012; Poch, R.M., Casamitjana, M., Francis., L.M., Eds.; Editions I publications de la Universitat de Lleida: Lleida, Spain, 2012; pp. 40-42.

14. Antisari, L.V.; Cremonini, S.; Desantis, P.; Calastri, C.; Vianello, G. Chemical characterisation of anthrotechnosols from Bronze to Middle Age in Bologna (Italy). J. Archaeol. Sci. 2013, 40, 3660-3671. [CrossRef]

15. Pawłowski, D.; Milecka, K.; Kittel, P.; Woszczyk, M.; Spychalski, W. Palaeoecological record of natural changes and human impact in a small river valley in Central Poland. Quat. Int. 2015, 370, 12-28. [CrossRef]

16. Thy, P.; Willcox, G.; Barfod, G.H.; Fuller, D.Q. Anthropogenic origin of siliceous scoria droplets from Pleistocene and Holocene archaeological sites in northern Syria. J. Archaeol. Sci. 2015, 54, 193-209. [CrossRef]

17. Golyeva, A.; Zazovskaia, E.; Turova, I. Properties of ancient deeply transformed man-made soils (cultural layers) and their advances to classification by the example of Early Iron Age sites in Moscow Region. Catena 2016, 137, 605-610. [CrossRef]

18. Shcherbakov, N.B.; Shuteleva, I.A.; Leonova, T.A.; Goleva, A.A.; Lunkova, Y.V.; Kraeva, L.A. The ceramic complex as reflection of intercultural exchange of the Late Bronze Age tribes of the Southern Transurals. In Proceedings of the Creativity: An Exploration through the Bronze Age and Contemporary Responses to the Bronze Age; Magdalene College, University of Cambridge: Cambridge, UK, 2013; pp. 32-33.

19. Shcherbakov, N.B.; Leonova, T.A.; Shuteleva, I.A.; Golyeva, A.A. Anthropogenetic factor of landscape change in the process of early urbanization on the territory of Southern Transurals. In Proceedings of the Environmental Archaeology of European Cities (CEAEC), Brussel, Belgium, 27-29 May 2015; pp. 80-81.

20. Abdrakthmanov, R.F.; Martin, V.I.; Popov, V.G.; Roshdestvenskij, A.P.; Smirnov, A.I.; Travkin, A.I. Karst of Bashkortostan; Ufa-Press: Ufa, Russia, 2002; pp. 5-128. (In Russian)

21. Golyeva, A.; Khokhlova, O.; Shcherbakov, N.; Shuteleva, I. Negative effects of Bronze age human activity on modern soils and landscapes, a case-study on the Muradymovo settlement, Urals, Russia. Interdiscip. Archaeol. Nat. Sci. Archaeol. 2016, 2, 169-178. [CrossRef]

22. Yaparov, I.M. Atlas of the Bashkortostan Republic; Kitap-Press: Ufa, Russia, 2005; p. 486. (In Russian)

23. IUSS Working Group WRB. World Reference Base for Soil Resources 2014-International Soil Classification System for Naming Soils and Creating Legends for Soil Maps; World Soil Resources Reports No. 106; Food and Agriculture Organization (FAO): Rome, Italy, 2014.

24. Bogomolov, L.V. Soils of Bashkiria ASSR; USSR Academy of Science Press: Moscow, Russia, 1954; pp. 1-296.

25. Khaziev, F. Kh. The Soil of the Republic of Bashkortostan and the Regulation of Their Fertility; Gilem-Press: Ufa, Russia, 2007; pp. 1-288. (In Russian) 
26. Obydennova, G.T.; Shcherbakov, N.B.; Shuteleva, I.A.; Khokhlova, O.S.; Kovaljuh, N.N.; Skripkin, V.V. Some results of the application of a complex approach at studying a monument of the Late Bronze Age in Bashkir Priuraljy-settlements Muradymovo. In Proceedings of the II (XVIII) All-Russian Archaeological Congress in Suzdal, 20-25 October 2008, Suzdal, Russia; Derevyanko, A.P., Makarov, N.A., Eds.; Institute of Archaeology of RAS: Moscow, Russia, 2008; pp. 435-438. (In Russian)

27. Shuteleva, I.A.; Shcherbakov, N.B.; Balonova, M.G.; Khokhlova, O.S.; Goleva, A.A. Some results of the application of a complex approach to the research of the Late Bronze age settlement in the Volgo-Ural region. Interdiscip. Archaeol. Nat. Sci. Archaeol. 2010, 1, 29-36.

28. Arinushkina, E.V. Guide on the Chemical Analysis of Soils; Moscow State University Publishing: Moscow, Russia, 1970. (In Russian)

29. Poch, R.M.; Artiedo, O.; Herrero, J.; Verba-Lebedeva, M. Gypsic features. In Interpretation of Micromorphological Features of Soils and Regoliths; Stoops, G., Marcelino, V., Mees, F., Eds.; Elsevier: Dutch, The Netherlands, 2010; pp. 195-216.

30. Vorobieva, L.A. Chemical Analysis of Soils; Publishing House of MSU: Moscow, Russia, 1998; pp. 3-260.

31. Bullock, P.; Fedoroff, N.; Jongerius, A.; Stoops, G.; Tursina, T. Handbook for Soil Thin Section Description; Waine Research Publication: Wolverhampton, UK, 1985; p. 152.

32. Afanasyeva, E.A. Chernozems of the Middle Russian Plain; Nauka Press: Moscow, Russia, 1966; pp. 1-223. (In Russian)

33. Khokhlova, O.S.; Kovalevskaya, I.S.; Oleynik, S.A. Records of climatic changes in the carbonate profiles of Russian Chernozems. Catena 2001, 43, 203-215. [CrossRef]

34. Khokhlova, O.S.; Kouznetsova, A.M. Carbonate accumulation morphology in a soil chronosequence in the southern Pre-Ural, Russia: Significance for Holocene paleoenvironmental reconstruction. Revista Mex. Cienc. Geol. 2004, 21, 185-194.

35. Hamond, F.W. Phosphate analysis of archaeological sediments. Landsc. Archeol. Ireland. 1983, 116, 47-80.

36. Holliday, V.T.; Gartner, W.G. Methods of soil P analysis in archaeology. J. Archaeol. Sci. 2007, 34, $301-333$. [CrossRef]

37. Golyeva, A. Soil researches on settlement Sosnovka IV (Moscow region). In Archaeology of Moscow Region; Engovatova, A., Ed.; Institute of Archaeology RAS: Moscow, Russia, 2014; Volume 10, pp. 64-74.

38. Verba, M.P.; Yamnova, I.A. Gypsum neoformations in nonirrigated and irrigated soils of the serozem zone. In Proceedings of the International Working Meeting on Soil Micromorphology, 8-13 July 1996, Moscow, Russia; Shoba, S., Gerasimova, M., Miedema, R., Eds.; Printing Service Centre Van Gils B.V.: Wageningen, The Netherlands, 1997; pp. 187-195.

39. Nettleton, W.D.; Nelson, R.E.; Brasher, B.R.; Derr, P.S. Gypsiferous soils in the western United States. Acid Sulfate Weather 1982, 147-168.

40. Minashina, N.G.; Shishov, L.L. Gypsum-Containing soils: Their distribution, genesis, and classification. Eurasian Soil Sci. 2002, 35, 240-249.

(C) 2018 by the authors. Licensee MDPI, Basel, Switzerland. This article is an open access article distributed under the terms and conditions of the Creative Commons Attribution (CC BY) license (http://creativecommons.org/licenses/by/4.0/). 